\title{
O LIMITE TÊNUE ENTRE LIBERDADE E ESCRAVIDÃO EM BENGUELA DURANTE A ERA DO COMÉRCIO TRANSATLÂNTICO*
}

\author{
Mariana P. Candido**
}

$\mathrm{N}$

as últimas décadas foram publicados vários estudos sobre a organização do tráfico de escravos e seu impacto nas sociedades africanas. Desde o clássico estudo de Philip Curtin (The Atlantic Slave Trade: A Census, 1969) historiadores preocupam-se com o volume do tráfico transatlântico. Com a disponibilização da nova versão da Trans-Atlantic Slave Trade Database e a publicação do Atlas of the Transatlantic Slave Trade, ${ }^{1}$ podemos estimar quantos escravos deixaram cada porto ao longo do litoral ocidental da África e seus portos de desembarque nas Américas. Os números, entretanto, não revelam como essas pessoas foram capturadas e reduzidas à escravidão; além disso, estudos quantitativos priorizam a experiência coletiva e não casos individuais. O resultado é que a historiografia tende a tratar os chamados "prisioneiros de guerra" como exemplos do modelo africano de

\footnotetext{
* A pesquisa para esse artigo foi financiada pelos Research Grant University Committee on Research e o Program of Latin American Studies da Universidade de Princeton, e por bolsas de pesquisa da Fundação Luso-Americana e da John Carter Brown Library. Agradeço a Mariza de Carvalho Soares, Carlos da Silva Jr, Vanessa de Oliveira, Nielson Bezerra e aos dois pareceristas anônimos pela leitura e sugestões.

** Professora do Departamento de História da Universidade de Princeton. mcandido@ princeton.edu

1 A base de dados está disponível online, no site http://www.slavevoyages.org/tast/database/ search.faces; e David Eltis e David Richardson, Atlas of the Transatlantic Slave Trade, New Haven: Yale University Press, 2010.
} 
escravização por excelência, negligenciando outras formas de captura que também resultaram em escravização. ${ }^{2}$ Fontes primárias sobre a colônia de Benguela permitem analisar como alguns indivíduos foram enganados, sequestrados, e escravizados, indicando como o limite entre liberdade e cativeiro era tênue. ${ }^{3}$ Este estudo prioriza casos em que, ainda que através de intermediários, os relatos dos cativos puderam ser ouvidos. Examino os traços que eles deixaram na documentação, revelando seus processos de captura. Os relatos permitem ao historiador entender a captura e a escravização como um processo singular e individual, uma alternativa à abordagem das experiências coletivas e anônimas que as análises demográficas priorizam. ${ }^{4}$

2 Para autores que privilegiam o papel das guerras nos processos de escravização, ver Jean Bazin, "War and Servitude in Segou", Economy and Society, v. 3 (1974), pp. 107-44; Philip Curtin, Economic Change in Precolonial Africa. Senegambia in the era of the Slave Trade, Madison: University of Wisconsin Press, 1975; Joseph Miller, "The Paradoxes of Impoverishment in the Atlantic Zone", in David Birmingham e Phyllis Martin (orgs.), History of Central Africa (Londres: Longman, 1983), pp. 118-59; John Thornton, Warfare in Atlantic Africa, 1500-1800, Londres: UCL Press, 1999; Robin Law, "Slave-raiders and Middlemen, Monopolist and Free Traders: The Supply of Slaves for the Atlantic Trade in Dahomey, c. 1715-1850", Journal of African History, v. 30 (1989), pp. 45-68; e Boubacar Barry, Senegambia and the Atlantic Slave Trade, Cambridge: Cambridge University Press, 1998.

3 O uso do termo colônia não é gratuito. Ver Mariana Candido, An African Slaving Port on the Atlantic World. Benguela and its Hinterland, Nova York: Cambridge University Press, 2013, pp. 30-87; Frederick Cooper, "Images of Empire, Contests of Conscience. Models of Colonial Domination in South Africa", in Frederick Cooper e Ann Laura Stoler (orgs.), Tensions of Empire: Colonial Cultures in a Bourgeois World (Berkeley: University of California Press, 1997), pp. 1-56; Frederick Cooper, Colonialism in Question: Theory, Knowledge, History, Berkeley: University of California Press, 2005; e Immanuel Wallerstein, World-Systems Analysis: An Introduction, Durham, NC: Duke University Press, 2004. Para outras colônias portuguesas ver Eugénia Rodrigues, "Cipaios da Índia ou soldados da terra? Dilemas da naturalização do exército português em Moçambique no século XVIII", História: Questões \& Debates, n. 45 (2006), pp. 57-95.

4 Para a importância de estudos biográficos de africanos escravizados ver Paul Lovejoy, "Identifying Enslaved Africans in the African Diaspora", in Paul E. Lovejoy (org.), Identity in the Shadow of Slavery (Londres: Cassell Academic, 2000), pp. 3-5; Luiz Mott, Rosa egipciaca uma santa africana no Brasil, Rio de Janeiro: Bertrand Brasil, 1993; Randy Sparks, The Two Princes of Calabar: An Eighteenth-Century Atlantic Odyssey, Cambridge: Harvard University Press, 2004; Flávio dos Santos Gomes, Marcus Joaquim de Carvalho e João José Reis, O Alufá Rufino. Tráfico, escravidão e liberdade no Atlântico Negro, São Paulo: Companhia das Letras, 2010; Karen Racine e Beatriz G. Mamigonian, The Human Tradition in the Atlantic World, 1500-1850, Lanham: Rowman \& Littlefield, 2010; James Sweet, Domingos Ailvares, African Healing, and the Intellectual History of the Atlantic World, Chapel Hill: University of North Carolina Press, 2011; Roquinaldo Ferreira, Cross-Cultural Exchange in the Atlantic World: Angola and Brazil during the Era of the Slave Trade, Nova Iorque: Cambridge University Press, 2012. Estudos sobre a vida de europeus na África são muitos. Ver, por exemplo Maria Emília Madeira Santos (ed.), Viagens e apontamentos 
Os casos explorados nesse estudo, assim como tantos outros disponíveis em diferentes fundos documentais, indicam que na região de Benguela a escravidão era uma ameaça a todos. A ideia defendida por Joseph Miller, e outros, de que a fronteira da escravidão moveu-se cronológica e progressivamente para o interior do continente africano, criando proteção para os habitantes do litoral, não se aplica a Benguela. ${ }^{5}$ Os relatos de indivíduos capturados próximos a esta costa e em regiões sob controle português, em locais supostamente protegidos pela fronteira escravista, demonstram como a escravidão tornou-se ameaçadora para os habitantes da região, e como eles buscavam meios de protegerse e poupar seus familiares do risco de captura e venda para comerciantes transatlânticos. Entre várias estratégias, estava a possibilidade de utilizar o sistema legal colonial que deveria proteger os súditos de po-

de um portuense em África. O Diário de Silva Porto, Coimbra: Biblioteca Geral, 1986; Zsófia Vajkai Gulyas, "Um húngaro em Angola: viagens de Ladislau Magyan: 1818-1864: através do AHU", in Actas do Seminário: Encontro de Povos e Culturas em Angola, Lisboa: Comissão Nacional para as Comemorações dos Descobrimentos Portugueses, 1997, 361-74; Ilídio do Amaral, O consulado de Paulo Dias de Novais: Angola no último quartel do século XVI e primeiro do século XVII, Lisboa: Ministério da Ciências e da Tecnologia, Instituto de Investigação Científica Tropical, 2000; Éve Sebestyeìn, Magyar László, Budapeste: Balassi Kiadoì, 2008; e Andrew C. Ross, David Livingstone: Mission and Empire, Londres: Continuum, 2006. Para biografias de africanos livres ver, entre outros, Carlos Pacheco, Arsénio Pompílio Pompeu de Carpo: uma vida de luta contra as prepotências do poder colonial em Angola, Lisboa : Instituto de Investigação Científica Tropical, 1992; John K. Thornton, The Kongolese Saint Anthony: Dona Beatriz Kimpa Vita and the Antonian Movement, 1684-1706, Cambridge: Cambridge University Press, 1998; Carlos Alberto Lopes Cardoso, "Ana Joaquina dos Santos Silva, industrial angolana da segunda metade do século XIX", Boletim Cultural da Câmara Municipal de Luanda, n. 3 (1972), pp. 5-14; Douglas Wheeler, "Angolan Woman of Means: D. Ana Joaquina dos Santos e Silva, Mid-Nineteenth Century Luso-African Merchant-Capitalist of Luanda", Santa Barbara Portuguese Studies Review, n. 3 (1996), pp. 284-97.

5 Ver Joseph C. Miller, Way of Death: Merchant Capitalism and the Angolan Slave Trade, 1730-1830, Madison: University of Wisconsin Press, 1988, pp. 140-69; David Birmingham, Trade and Conflict in Angola: The Mbundu and Their Neighbours Under the Influence of the Portuguese, 1483-1790, Oxford: Clarendon Press, 1966; Dennis Cordell, "The Myth of Inevitability and Invincibility: Resistance to Slavery and the Slave Trade in Central Africa, 1850-1910", in Sylviane A. Diouf (org.), Fighting the Slave Trade: West African Strategies (Athens: Ohio University Press, 2003), pp. 31-4; Paul Lovejoy e David Richardson, “'Pawns Will Live When Slaves Is Apt to Dye': Credit, Slaving and Pawnship at Old Calabar in the Era of the Slave Trade", Working Papers in Economic History, v. 38 (1997), pp. 1-34; e Jan Vansina, Kingdoms of the Savanna, Madison: University of Wisconsin Press, 1966. Para uma extensa crítica ao modelo organizado e progressivo do movimento da fronteira da escravização ver Mariana P. Candido, Fronteras de esclavización. Esclavitud, comercio e identidad em Benguela, 1780-1850, Cidade del México: El Colegio de México, 2011. 
tentados que haviam declarado vassalagem à Coroa portuguesa. ${ }^{6}$ Tais casos demonstram que algumas das pessoas capturadas, e que possivelmente seriam vendidas como escravas para comerciantes transatlânticos vieram de localidades próximas à costa ou eram residentes em Benguela Algumas delas falavam português, ainda que de forma limitada, e haviam sido expostas ao catolicismo. Para as pessoas capturadas próximas à costa, a escravidão não começou nas Américas nem nos portos de embarque, mas no momento de sua captura, quando foram separadas de seus familiares e comunidades. ${ }^{7}$

Usando caso de indivíduos que resistiram à sua escravização, esse estudo dialoga com a historiografia sobre o tráfico de escravos e a expansão da escravidão no continente africano no contexto do comércio atlântico. Na maioria dos casos não sabemos o final do processo legal, mas a documentação sugere um esforço coletivo para salvar familiares e amigos próximos. Os processos judiciais hoje disponíveis no Arquivo Nacional da Torre do Tombo, em Lisboa, e no Arquivo Histórico Nacional de Angola, em Luanda, revelam também o debate jurídico sobre a legalidade da escravidão; ao invés de minimizar o impacto do tráfico de escravos, eles permitem compreender quem deveria ser protegido das garras dessa instituição. ${ }^{8}$ Baseada nesses documentos, procuro enfatizar o poder destruidor da presença portuguesa e da expansão do comércio atlântico na região de Benguela.

6 Para maior discussão sobre como teoricamente a vassalagem deveria proteger os vassalos da Coroa portuguesa, ver Ferreira, Cross-Cultural Exchanges in the Atlantic World, 2012, pp. 52-87; José C. Curto, "The Story of Nbena, 1817-1820: Unlawful Enslavement and the Concept of 'Original Freedom' in Angola", in Paul E. Lovejoy e David V. Trotman (orgs.), TransAtlantic Dimensions of Ethnicity in the African Diaspora (Londres: Continuum, 2003), pp. 44-64; Candido, Fronteras de Esclavización, pp. 155-90. Para os direitos dos vassalos, ver Beatriz Heintze, "Luso-African Feudalism in Angola? The Vassal Treaties of the 16th to the 18th Century", Separata da Revista Portuguesa de História, v. 18 (1980), pp. 111-31; e Ana Paula Tavares e Catarina Madeira Santos, "Uma leitura africana das estratégias políticas e jurídicas. Textos dos e para os Dembos", in Africae Monumenta. A apropriação da escrita pelos africanos, Lisboa: IICT, 2002.

7 Para uma posição contrária, ver Stephanie E. Smallwood, Saltwater Slavery: A Middle Passage from Africa to American Diaspora, Cambridge: Harvard University Press, 2007.

8 Para estudos que minimizam os efeitos do tráfico transatlântico na África Centro Ocidental, ver John Thornton, "The Slave Trade in Eighteenth Century Angola: Effects of Demographic Structure", Canadian Journal of African Studies, v. 14, n. 3 (1980), pp. 417-27; e Joseph C. Miller, "The Significance of Drought, Disease and Famine in the Agriculturally Marginal Zones of West-Central Africa", Journal of African History, v. 23, n. 1 (1982), pp. 17-61. 
Mais de 760.000 escravos foram embarcados em Benguela, o terceiro maior porto escravagista na costa africana. ${ }^{9} \mathrm{O}$ comércio de escravos era antigo e provavelmente precedia a chegada dos portugueses, mas a presença dos navios transatlânticos e das forças coloniais alterou a dimensão desse comércio. Já em 1618, um ano após a fundação da conquista portuguesa, o primeiro governador de Benguela, Manoel Cerveira Pereira, despachou navios com escravos para Luanda. ${ }^{10}$ Inicialmente, os escravos eram enviados a Luanda por mar, onde pagavam imposto e eram reembarcados para as Américas. Um comércio paralelo também devia existir, devido à atuação dos comerciantes portugueses nos asientos nas colônias da América espanhola, o que explica a existência de escravos identificados como "benguelas" em Havana, Lima e Cartagena ainda no século XVII, antes da abertura de uma alfândega para a cobrança de imposto naquele porto. ${ }^{11}$ A maior parte dos escravos exportados de Benguela no século XVII era adquirida em "guerras de conquista". Desde então, a população local, conhecida pelas forças portuguesas como mundombes, ou ndombes, foi alvo dos comerciantes locais e a principal fonte de escravos para revenda em Benguela. Esse comércio era regulado por leis locais, às quais temos acesso limitado. As razias e sequestros predominaram nos primeiros anos de contato, mas muito cedo a Coroa portuguesa percebeu a importância de atuar com a colaboração e consentimento dos estados e potentados locais, priorizando o comércio. ${ }^{12}$ Nesse contexto

9 Somente os portos de Luanda e Ouidah viram um número maior de pessoas serem vendidas e embarcadas como escravos. Ver David Eltis e David Richardson, Atlas of the Transatlantic Slave Trade; e Paul E. Lovejoy, Transformations in Slavery, Nova York: Cambridge University Press, 2012, $3^{\text {a }}$ edição, p. 19.

10 Adriano Parreira, “A primeira 'conquista' de Benguela (Século XVII)”, História, v. 28 (1990), p. 67. Para maiores detalhes sobre a autonomia de Benguela ver Candido, Fronteras de esclavización, pp. 44-57.

11 No entanto, não há registro de exportação de escravos desde o porto de Benguela no século XVII na documentação portuguesa. Candido, An African Slaving Port on the Atlantic World, pp. 142-90. Ver também, Roquinaldo Ferreira, "Slaving and Resistance to Slaving in West Central Africa", in David Eltis e Stanley L Engerman (orgs.), The Cambridge World History of Slavery, $A D$ 1420-AD 1804, v. 3 (Nova York: Cambridge University Press, 2011), p. 116.

12 Para a atuação da Coroa portuguesa em outras partes da costa da África, ver Toby Green, The Rise of the Trans-Atlantic Slave Trade in Western Africa, 1300-1589, Nova York: Cambridge University Press, 2011. Eu uso o conceito de estado para indicar organizações políticas com um governo centralizado, que mantêm o monopólio do uso legítimo da força dentro de seu território, conta com uma burocracia e um sistema legal (na maioria das vezes oral). Para definição de estado ver Peter Lassman e Ronald Speirs, Weber, Political Writings, Cambridge: Cambridge 
surgiram debates sobre a legalidade dos processos de escravização no primeiro século de ocupação. No século XVIII, a criação de novos cargos para controle do comércio, como o inquiridor das liberdades, demonstra que o processo de escravização incluía casos de pessoas capturadas em contextos que não eram de "guerra justa", como as guerras de conquistas também ficaram conhecidas. ${ }^{13}$

Apesar de um decreto de 1612 ter instituído Benguela como reino independente de Angola com governador próprio, após a expulsão dos holandeses em 1648, Benguela passou a ser governada por um capitãomor, apontado pelo governador de Angola e aprovado pelo Conselho Ultramarino em Lisboa. ${ }^{14}$ Entre outras responsabilidades, o capitão-mor governava a cidade de Benguela, supervisionava e autorizava despachos de navios negreiros, aprovava a circulação dos comerciantes ambulantes, controlava a venda de alimentos no porto e as atividades dos comerciantes de escravos de um modo geral. Desse modo, centralizava as atividades mercantis em suas mãos, em especial o comércio de escravos. ${ }^{15}$ Após

University Press, 1994, pp. 310-12. Para casos que se aplicam ao contexto da África centro ocidental, ver Jan Vansina, "Equatorial Africa and Angola: Migrations and the Emergence of the First States", in D. T. Niane (org.), General History of Africa, v. IV (Paris: UNESCO, 2000), pp. 551-77; Joseph C. Miller, "Kings, Lists, and History in Kasanje", History in Africa, v. 6 (1976), pp. 51-96; e John Thornton, "The Kingdom of Kongo, ca. 1390-1678", Cahiers d'Études Africaines, v. 22, n. 87/88 (1982), pp. 325-42. Para a definição de chefatura, ver Igor Kopytoff, "Permutations in Patrimonialism and Populism: The Aghem Chiefdoms of Western Cameroon", in Susan Keech McIntosh (org.), Beyond Chiefdoms: Pathways to Complexity in Africa (Cambridge University Press, 1999), pp. 88-96; e Jan Vansina, "Pathways of Political Development in Equatorial Africa and Neo-evolutionary Theory", in McIntosh (org.), Beyond Chiefdoms: Pathways to Complexity in Africa (Cambridge University Press, 1999) pp. 166-72.

13 Sobre o conceito de guerra justa ver Beatriz Perrone-Moisés, "A guerra justa em Portugal no século XVI", Revista da SBPH: Sociedade Brasileira de Pesquisa Histórica, n. 5 (90 1989), pp. 5-10; Lauren Benton, "The Legal Regime of the South Atlantic World, 1400-1750: Jurisdictional Complexity as Institutional Order", Journal of World History, v. 11, n. 1 (2000), pp. 27-56; e Angela Domingues, "Os conceitos de guerra justa e resgate e os ameríndios do Norte do Brasil", in Maria B. N. Silva (org.), Brasil: colonização, escravidão (Rio de Janeiro: Nova Fronteira, 2000).

14 Para o decreto do rei Felipe II de Portugal (III da Espanha) ver, AHU, Conselho Ultramarino, Angola, caixa 1, doc. 20,11, março de 1612. A separação dos reinos foi baseado na sugestão de Domingo de Abreu e Brito, Inquérito da Vida Administrativa e Económica de Angola, Coimbra: Imprensa da Universidade, 1931, p. 3.

15 Arquivo Nacional da Torre do Tombo (ANTT), Conde de Linhares, mç. 42, doc. 2, 3 de fevereiro de 1775. Ver também Ralph Delgado, Reino de Benguela. Do descobrimento a criação do governo subalterno, Lisboa: Imprensa Beleza, 1945, p. 383; e Miller, Way of Death, pp. 264-8. 
alguns anos, a Coroa portuguesa resolveu retornar ao sistema de governador em Benguela. O primeiro governante a retomar o cargo foi António José Pimental de Castro e Mesquita, nomeado em 1779. Mesmo tendo o título de governador continuava subordinado ao de Angola. Entretanto, devido à distância e ao fato da ligação com Luanda ser exclusivamente marítima, as autoridades de Benguela desfrutavam de relativa autonomia. ${ }^{16} \mathrm{O}$ governante de Benguela também administrava os presídios da conquista, ou seja, as fortalezas portuguesas estabelecidas em pontos importantes para o controle das caravanas que traziam produtos para o comércio de longa distância, geralmente em terras de sobas avassalados. Assim, antes de 1779, o capitão-mor e posteriormente o governador de Benguela fiscalizavam a função de capitães-mores que administravam os presídios no sertão. Os presídios representavam o avanço colonial português no território e funcionavam como centros administrativos e militares, com uma pequena força armada responsável pela segurança, coleta de impostos, controle e proteção das rotas comerciais e das caravanas. $\mathrm{O}$ presídio de Caconda, o mais importante e distante, ficava a 240 quilômetros da cidade de Benguela, enquanto Quilengues a cerca de 220 quilômetros. O território entre Benguela e os presídios no interior não estavam sob controle das forças portuguesas, e sim de sobados que poderiam ser, ou não, vassalos do reino de Portugal. Assim sendo, os presídios funcionavam como espaços "portugueses" em regiões onde a maioria da população não estava sob domínio colonial. No interior dos muros das fortalezas, geralmente feitos de pau-a-pique, havia um quartel, a casa da administração, uma igreja, a casa da câmara, habitações dos soldados e uma horta. Vários africanos livres que viviam aí frequentavam a igreja e batizavam os seus filhos. ${ }^{17}$ Faziam parte, ainda que de forma temporária e

${ }^{16}$ A área da Quissama era uma região de constantes conflitos entre tropas portugueses e autoridades africanas. Ver Beatrix Heintze, "Historical Notes on the Kisama of Angola", Journal of African History, v. 13, n. 3 (1972), pp. 407-18.

17 Roquinaldo Ferreira, "Ilhas Crioulas": o significado plural da mestiçagem cultural na África Atlântica", História, v. 155, n. 2 (2006), pp. 17-41; Mariana P. Candido, "Benguela et l'espace atlantique sud au XVIIIe siècle", Cahiers des Anneux de la Mémoire, v. 14 (2011), pp. 22343; José Curto, “'As If From a Free Womb:' Baptismal Manumissions in the Conceição Parish, Luanda, 1778-1807", Portuguese Studies Review, v.10, n. 1 (2002), pp. 26-57; e Selma Pantoja, "Inquisição, degredo e mestiçagem em Angola no século XVII", Revista Lusófona de Ciência das Religiões, v. 3, n. 5/6 (2004), pp. 117-36. 
superficial, de uma comunidade luso-africana, como definiu a historiadora Beatrix Heintze. ${ }^{18}$ No entanto, vassalagem não significa aculturação ou subjugação completa. Apesar de a autonomia política ter sido comprometida com o afastamento de líderes que resistiam aos avanços portugueses, os sobas que haviam assinado os tratados de vassalagem continuavam a exercer hegemonia comercial em seus territórios, exigindo pagamento de tributos na forma de produtos trazidos do Atlântico e acordos comerciais que reforçavam o poderio militar dessas lideranças africanas nos territórios fora das fortificações portuguesas. ${ }^{19}$

Nesse estudo, discuto os casos de indivíduos capturados e escravizados na região entre o porto de Benguela e os presídios de Caconda e Quilengues. Desde o século XVII, um número desconhecido de escravos do que se convencionou chamar Benguela desembarcou em vários portos das Américas. Além dos prisioneiros de guerra, muitos foram sequestrados ou enganados, e alguns deles residiam em Benguela ou nos presídios portugueses. Ao chegar ao Brasil, muitos deles provavelmente foram considerados crioulos de Benguela, ou ladinos, por já terem algum conhecimento do português e já estarem familiarizados com o colonialismo. A experiência em Benguela deve ter provocado um efeito profundo na forma como eles entendiam a escravidão nas Américas. Alguns desses indivíduos foram capazes de questionar a sua escravidão, alegando, entre outras coisas, serem vassalos da Coroa portuguesa, assunto esse já tratado anteriormente. ${ }^{20}$

18 Beatrix Heintze, "A lusofonia no interior da África Central na era pré-colonial. Um contributo para a sua história e compreensão na actualidade", Cadernos de Estudos Africanos, v. 6-7 (2005), pp. 179-207.

19 Beatrix Heintze e Catarina Madeira Santos têm escrito sobre vassalagem em Angola. Ver Beatrix Heintze, "The Angolan Vassal Tributes of the 17th Century", Revista de História Económica e Social, n. 6 (1980), pp. 57-78; Beatrix Heintze, "Ngingi a Mwiza: um sobado angolano sob domino português no século XVII", Revista Internacional de Estudos Africanos, n. 8-9 (1988), pp. 221-34; Heintze, "Luso-African Feudalism in Angola? pp. 111-31; Catarina Madeira Santos, "Administrative Knowledge in a Colonial Context: Angola in the Eighteenth Century", The British Journal for the History of Science, v. 43, n. especial Issue 4 (2010), pp. 539-56; Catarina Madeira Santos, "Escrever o poder: os autos de vassalagem e a vulgarização da escrita entre as elites africanas Ndembu", Revista de História, n. 155 (2006), pp. 81-95; Tavares e Madeira Santos, "Uma leitura africana das estratégias políticas e jurídicas", pp. 243-60.

20 Mariana P. Candido, "African Freedom Suits and Portuguese Vassal Status: Legal Mechanisms for Fighting Enslavement in Benguela, Angola, 1800-1830", Slavery \& Abolition, v. 32, n. 3 (2011), pp. 447-59. 


\section{Fontes e como recuperar a voz dos escravos africanos}

Os estudos sobre o tráfico transatlântico de escravos tendem a dar ênfase ao volume e aos mecanismos de crédito $^{21}$ e poucos são aqueles que enfatizam os processos de escravização. Muito do que sabemos sobre captura e escravidão vem de relatos de africanos que sobreviveram à travessia Atlântica e aos anos de escravidão nas Américas. Alguns deles deixaram relatos que foram editados por abolicionistas e missionários protestantes. Quase todos esses relatos tratam do final do século XVIII e do começo do século XIX, época do apogeu do tráfico. Geralmente são lidos como exemplos quase ahistóricos da escravidão e utilizados para explicar processos de captura do século XVII, ou de regiões do continente africano distantes dos locais dos fatos narrados. Por fim, tendem a enfatizar os maus tratos e as condições de vida nas Américas, a maior parte deles relativos ao que hoje constitui os Estados Unidos. Poucos falam de outras partes das Américas e, por fim, quase todos negligenciam ou tratam muito superficialmente dos processos de captura e escravização no continente africano.

Narrativas de captura, processo de escravização, transporte em caravanas até a chegada aos portos marítimos, assim como a venda para comerciantes europeus e a travessia do Atlântico estão disponíveis nas autobiografias de Olaudah Equiano, ou Gustavus Vassa, Quobna Ottobah Cugoano e Mahommah Gardo Baquaqua, escravos africanos que deixaram registros. As três narrativas têm em comum o fato de seus atores terem escrito suas próprias memórias depois de terem sido sequestrados e vendidos como escravos ainda jovens (Cugoano e Vassa eram crianças, Baquaqua tinha aproximadamente 20 anos). ${ }^{22}$ Autobiografias não são a

${ }^{21}$ José C. Curto, "The Legal Portuguese Slave Trade from Benguela, Angola, 1730-1828: A Quantative Re-appraisal", África, v. 17, n. 1 (1993/1994), pp. 101-16; Joseph C. Miller, "Some Aspects of the Commercial Organization of Slaving at Luanda, Angola - 1760-1830", in Henry Gemery e Jan Hogendorn (orgs.), The Uncommon Market: Essays in the Economic History of the Atlantic Slave Trade (Nova York: Academic Press, 1979), pp. 77-106; Roquinaldo Ferreira, "Dinâmica do comércio intra-colonial: geribitas, panos asiáticos e guerra na tráfico angolano de escravos (século XVIII)", in João Fragoso, Maria de Fátima Silva Gouvêa e Maria Fernanda Baptista Bicalho (orgs.), O antigo regime nos trópicos: a dinâmica imperial portuguesa (séculos XVI-XVIII) (Rio de Janeiro: Civilização Brasileira, 2001), pp. 339-78, e Daniel B. Domingues da Silva, "The Supply of Slaves from Luanda, 1768-1806: Records of Anselmo da Fonseca Coutinho", African Economic History, v. 38 (2010), pp. 53-76.

22 Robin Law e Paul E. Lovejoy (orgs.), The Biography of Mahommah Gardo Baquaqua: His Passage 
única forma de analisar como as pessoas foram escravizadas. Randy Sparks recriou a saga de Little Ephraim Robin John e Ancona Robin Robin John, ambos parte da elite comercial e política de Old Calabar que foram ilegalmente transportados para a ilha de Dominica, no Caribe, e vendidos como escravos depois de empenhados a comerciantes atlânticos como moeda de segurança para o pagamento de créditos. Recentemente, usando fontes inquisitoriais e registros policiais, James Sweet publicou a biografia de Domingos Álvares, um escravo africano capturado no Daomé e vendido em Jakin a comerciantes negreiros que cruzaram o Atlântico passando por Pernambuco, Rio de Janeiro, Lisboa e por fim Castro Marim, no Algarve. ${ }^{23}$ Ou ainda, João José Reis e a saga de outro Domingos, Sodré, de Onim, um reino de língua iorubá, que atuava como sacerdote na Bahia no século XIX. ${ }^{24}$ Mariza de Carvalho Soares investiga a importância do passado africano do casal Victória Coura e Ignácio Mina na organização de irmandades católicas no Rio de Janeiro durante o século XVIII, cujas fontes não permitem reconstruir processos de captura no continente africano. ${ }^{25}$

As poucas autobiografias existentes - a maior parte disponível somente em inglês - tem representado o relato modelo dos processos de captura. Em sua totalidade se referem a indivíduos oriundos da região entre o rio Senegal e a baía de Biafra, conhecida como a África Ocidental, e não da região centro ocidental de onde vieram a maioria dos escra-

from Slavery to Freedom in Africa and America (Princeton: Markus Wiener Publishers, 2001), pp. 136-38; Olaudah Equiano, The Interesting Narrative of the Life of Olaudah Equiano or Gustavus Vassa, the African, Londres: Edição do autor, 1794; e Quobna Ottobah Cugoano, Thoughts and Sentiments on th Evil of Slavery, Nova York: Penguin, 1999. Para o debate sobre o uso do nome Olaudah Equiano ou Gustavus Vassa, como o próprio autor preferia, ver Vincent Carretta, Equiano, the Africa: Biography of a Self-Made Man, Athens: University of Georgia Press, 2005; e Paul E. Lovejoy, "Issues of Motivation-Vassa/Equiano and Carretta's Critique of the Evidence", Slavery and Abolition, v. 28, n. 1 (2007), pp. 121-25.

23 James H. Sweet, Domingos Álvares.African Healing, and the Intellectual History of the Atlantic World, Chapel Hill: University of North Carolina Press, 2011.

24 João José Reis, Domingos Sodré, um sacerdote africano. Escravidão, liberdade e candomblé na Bahia do século XIX, São Paulo: Companhia das Letras, 2008.

25 Mariza de Carvalho Soares, "Can Women Guide and Govern Men?" Gendering Politccs among African Catholics in Colonial Brazil", in Gwyn Campbell, Suzanne Miers, e Joseph Miller (orgs.), Women and Slavery, The Modern Atlantic (Athens: Ohio University Press, 2008), pp. 79-99; e Mariza de Carvalho Soares, "African, esclave et roi: Ignacio Monte et sa cour à Rio de Janeiro au XVIIIe siècle”, Brésil(S) Sciences Humaines et Sociales, v. 1 (2012), pp. 13-32. 
vizados desembarcados nas Américas, oriundos em especial do antigo reino do Congo e das colônias portuguesas de Angola e Benguela. Apesar de a historiografia não mostrar ainda nenhuma documentação que forneça autobiografias de escravos centro africanos, alguns estudos começam a ser publicados, explorando esse segmento dos mais de cinco milhões de africanos capturados e deportados dessa região. ${ }^{26}$

Este artigo dialoga com os estudos disponíveis, buscando encontrar padrões de violência e analisar como, quando e onde pessoas livres tiveram a sua liberdade usurpada e se, na sequência, foram escravizadas. A reconstrução dessas histórias é possível através do uso das fontes coloniais portuguesas, principalmente a correspondência oficial, que relata debates sobre a legalidade da escravidão sob a ótica portuguesa. Assim, é possível afirmar que a escravidão era uma instituição altamente ordenada, com claros limites entre aqueles que estavam protegidos pela lei e não podiam ser escravizados e aqueles que se encontravam em posição vulnerável. Apesar de a voz do escravo estar ausente ou ter sido filtrada em muitos desses casos, a documentação colonial revela as histórias desses indivíduos, as circunstâncias da captura e os mecanismos empregados por familiares para reverter a condição escrava de seus parentes. Numa clara indicação de que em Benguela a escravidão tinha um fundo comercial, familiares, autoridades e seus representantes agiam rápido para proteger seus dependentes e evitar que fossem escravizados. Fica claro que a escravidão não era considerada benigna ou uma extensão de laços de dependência econômica e política, como Suzanne Miers e Igor Kopytoff caracterizaram a escravidão na África. ${ }^{27}$

A documentação colonial é limitada e se restringe a casos que chamaram a atenção das autoridades. É particularmente silenciosa quanto a processos de captura em estados independentes, fora da alçada da

26 José C. Curto, "The Story of Nbena, 1817-20: Unlawful Enslavement and the Concept of 'Original Freedom' in Angola”, in Paul E. Lovejoy e David Trotman (orgs.), Trans-Atlantic Dimensions of Ethnicity in the African Diaspora (Nova York: Continuum, 2003), pp. 43-64; Candido, Fronteras de esclavización, pp. 155-203; e Ferreira, "Slaving and Resistance to Slaving".

27 Para um estudo clássico que defende a escravidão africana como distinta e mais cordial que em outros lugares, ver Suzanne Miers e Igor Kopytoff, Slavery in Africa: Historical and Anthropological Perspectives, Madison: University of Wisconsin Press, 1975, pp. 3-76. 
Coroa portuguesa. As autoridades portuguesas reconheciam as leis locais como válidas no caso de pessoas escravizadas no interior, em regiões fora do controle da Coroa portuguesa, ${ }^{28}$ por isso os pombeiros, agentes comerciais e autoridades africanas chegados do sertão não precisavam justificar ou explicar as circunstâncias em que seus escravos vindos nas caravanas eram adquiridos. ${ }^{29}$ Reconhecendo o número limitado de casos que atraíram a atenção e deliberação de autoridades coloniais, enfatizamos as informações sobre o método de captura e a discussão sobre a legalidade da escravidão. Esses casos não são a exceção, são a ponta do iceberg. Revelam a vulnerabilidade dos africanos no entorno de Benguela e como suas vidas foram profundamente alteradas pela presença dos comerciantes transatlânticos e do estado colonial. Depois de décadas de domínio dos estudos quantitativos sobre o tráfico, o esforço deste texto é dialogar com os estudos recentes que priorizam as pessoas e suas estratégias individuais. Hoje temos mais informação sobre as condições de transporte durante a travessia atlântica e sobre os laços de solidariedade que permaneceram durante a escravidão no Brasil. ${ }^{30}$ Devemos olhar também com mais atenção para os processos de captura e escravização e como eles marcaram os africanos que chegaram às Américas.

\section{A legalidade da escravidão}

A legitimidade de submeter povos considerados gentios à escravidão ganhou destaque com a expansão portuguesa. Estimulada pela expul-

${ }^{28}$ Para mais detalhes, ver Candido, Fronteras de esclavización, pp. 161-62.

${ }^{29}$ Os pombeiros eram agentes comerciais que atuavam no interior como comerciantes volantes. Geralmente eram escravos, mas alguns eram livres. Ver Willy Bal, "Portugais Pombeiro 'Commerçant Ambulant Du 'Sertão", Annali: Istituto Universitario Orientale, v. 7, n. 2 (1965), pp. 123-61; Isabel Castro Henriques, "Percursos da modernidade em Angola. Dinâmicas comercias e transformações sociais no século XIX, Lisboa: Instituto de Investigação Científica Tropical, 1997, p. 765, e Candido, "Merchants and the Business of the Slave Trade", pp. 3-4.

30 Jaime Rodrigues, O infame comércio. Proposta e experiências no final do tráfico de africanos para o Brasil, Campinas: Unicamp, 2000; e Jaime Rodrigues, De costa a costa. Escravos, marinheiros e intermediários do tráfico negreiro de Angola ao Rio de Janeiro (17801860), São Paulo: Companhia das Letras, 2005; Walter Walthorne, "Being Now as It Were One Family": Shipmate Bonding on the Slave Vessel Emilia in Rio de Janeiro and throughout the Atlantic World", Luso-Brazilian Review, v. 45, n.1 (2008), pp. 53-76. 
são dos muçulmanos e judeus e autorizada pela aprovação do resgate, ou sequestro, dos povos da Guiné, a Coroa portuguesa estava comprometida com a captura e escravização dos povos não cristãos, justificando assim a expansão portuguesa, com o apoio da Igreja Católica. Influenciada pela tradição das cruzadas dos séculos anteriores, a bula papal Dum Diversas de 1452, por exemplo, autorizava o rei de Portugal a atacar, conquistar e submeter povos pagãos, sarracenos e inimigos de Cristo. ${ }^{31}$ A disposição papal também reconhecia o direito da Coroa portuguesa de apreender bens materiais e ocupar territórios habitados por esses povos e escravizá-los permanentemente. Assim, a expansão portuguesa pela costa da África deve ser entendida no contexto do conflito religioso na Península Ibérica e no Mediterrâneo, principalmente quando os portugueses encontraram muçulmanos na costa da Senegâmbia e utilizaram a lógica dos conflitos entre cristãos e muçulmanos para legitimar a sua captura e escravização. ${ }^{32}$

Com o estabelecimento da feitoria de Arguim na costa da Mauritânia em meados do século XV, as razias e conflitos bélicos deram lugar ao comércio, o que exigia uma nova bula papal determinando como as trocas comerciais entre povos africanos gentios e portugueses católicos deveriam ser justificadas nessa lógica de expansão comercial e religiosa. Aliada ao plano de conversão das populações locais, ao reconhecer o direito português sobre o monopólio do comércio com o Marrocos e as Índias, a bula papal Romanus Pontifex, de 1455, reforçava a ação da Coroa portuguesa na costa africana. Com o beneplácito da Igreja Católica, Portugal viu suas ações de sequestro e comércio de escravos reconhecidas como legítimas e essenciais para a expansão do cristianismo. ${ }^{33}$ A legalidade das bulas Dum Diversas e Romanus Pontifex

31 António Brásio, Monumenta Missionária Africana. África Ocidental (1342-1499), Lisboa: Agência Geral do Ultramar, 1958, v. I, pp. 269-73.

32 Barry, Senegambia and the Atlantic Slave Trade, pp. 27-49; e Green, Rise of the TransAtlantic Slave Trade, pp. 177-296.

33 A. J. R. Russell-Wood, "Iberian Expansion and the Issue of Black Slavery: Changing Portuguese Attitudes, 1440-1770", American Historical Review, v. 83, n. 1 (1978), pp.16-42; Ângela Domingues, Quando os índios eram vassalos. A colonização e relações de poder no norte do Brasil na segunda metade do século XVIII, Lisboa: Comissão Nacional para as Comemorações dos Descobrimentos Portugueses, 2000; e Alida Metcalf, Go-Between and the Colonization of Brazil, 1500-1600, Austin: University of Texas Press, 2005, p. 168. 
foi posteriormente reforçada com a promulgação de bulas semelhantes pelo papa Alexandre VI, em 1503, que conferiam aos espanhóis poderes sobre a população indígena do continente americano. Essas ideias ganharam maior substância e justificativa com o processo de colonização no Brasil, caracterizado pela violenta expulsão da população indígena e sua captura. A mesma lógica que justificava o resgate de africanos na Senegâmbia no século XV fundamentava a escravidão dos chamados povos gentios das Américas. ${ }^{34}$

O cronista português quinhentista Gomes Eanes de Zurara descreveu como no norte da África e na chamada Guiné os capitães de navios e marinheiros invocavam santos católicos e o rei de Portugal em seus ataques para captura de negros, fossem eles muçulmanos ou não. ${ }^{35}$ Seu relato deixa claro como o resgate era visto por um prisma religioso: ao invocar a Bíblia e o pecado de Ham, Zurara argumentava que os africanos deveriam ser escravizados pelo pecado ancestral. $\mathrm{O}$ mesmo argumento era usado para os povos chamados "canibais" que, por violarem as leis de Deus, estavam sujeitos à escravidão. Assim, povos "sem fé, rei ou lei," eram passíveis de viver em cativeiro. ${ }^{36}$

Não sabemos, entretanto, como autoridades africanas que ocupavam Benguela e seu sertão definiam a escravidão nos séculos XVII e XVIII. A pouca informação relativa às leis locais disponível tende a

${ }^{34}$ Charles R. Boxer, O Império marítimo português, São Paulo: Companhia das Letras, 2002; Luiz Felipe de Alencastro, O trato dos viventes. A formação do Brasil no Atlântico Sul, séculos XVI e XVII, São Paulo: Companhia das Letras, 2000.

35 Gomes Eanes de Zurara, Chronicas do descobrimento da Guiné, Paris: J.P. Aillaud, 1841, pp. 70-6; 93-7; 120-22; 157-60; 200-1; 212-5, entre outras passagens.

36 A. C. Saunders, História social dos escravos e libertos negros em Portugal (1441-1555), Lisboa: Imprensa Nacional, 1994, pp. 38-9; e António Manuel Hespanha e Catarina Madeira Santos, "Os poderes num império oceânico", in António Manuel Hespanha (org.), História de Portugal - O Antigo Regime v. 4 (1620-1807) (Lisboa: Estampa, 1993), p. 396. Para canibalismo e escravidão, ver Beatrix Heintze, "Contra as teorias simplificadoras. O 'canibalismo' na Antropologia e História da Angola", in Manuela Ribeiro Sanches (org.), Portugal não é um país pequeno. Contar o "Império" na pós-colonidade (Lisboa: Cotovia, 2006), pp. 223 22. Sobre a ideia de liberdade original, ver Curto, "The Story of Nbena, pp. 43-64. Para o uso da legislação portuguesa em Angola, ver Catarina Madeira Santos, "Entre deux droits: les lumières en Angola (1750-v.1800)", Annales - Histoire, Sciences Sociales, v. 60, n. 4 (2005), pp. 817-48. Sobre como a escravidão era definida em alguns sobados no interior de Benguela, ver Candido, Fronteras de esclavización, pp. 163-78. Para semelhanças com a legislação referente à população indígena nas Américas, ver John Manuel Monteiro, Negros da terra: índios e bandeirantes nas origens de São Paulo, São Paulo: Companhia das Letras, 1994. 
concentrar-se ao século XIX e revela que portugueses e africanos concordavam na existência de meios legítimos e ilegítimos de capturar e escravizar alguém. A ideia de guerra justa contra os que resistiam ao cristianismo promovia a legalidade da escravidão daqueles que não eram vassalos e aliados da Coroa portuguesa. Conceitos como guerra justa e liberdade original eram empregados por oficiais coloniais portugueses e autoridades religiosas para decidir o destino dos africanos que chegavam a contestar sua captura.

Essa justificativa religiosa da escravidão desencadeou um novo debate sobre a possibilidade de escravizar africanos convertidos ao cristianismo, como o caso da conversão do rei do Congo e sua corte, em 1491. Juristas e administradores se perguntavam se era legítimo e correto vender africanos que viviam como cristãos. ${ }^{37}$ No século XVII, por exemplo, padres jesuítas se questionavam sobre a legitimidade da tráfico de escravos em Luanda. Em 1610, Luís Brandão, reitor do Colégio da Companhia de Jesus, em Luanda, respondia às indagações sobre se todos os cativos que se encontravam no porto haviam sido capturados legalmente, ou seja, em conflitos com as forças portuguesas. Brandão argumentou que seria impossível averiguar as circunstâncias de cada captura e que os comerciantes os compravam e embarcavam de boa fé, acreditando nos intermediários que os enviavam aos mercados no interior e depois os traziam até a costa. Assim, segundo ele, o comércio devia continuar pois mais valia salvar almas do que deixar a população sem conhecer a fé cristã. ${ }^{38} \mathrm{E}$ a escravidão passou a ser justificada como parte do processo de conversão dos povos gentios.

Outros teólogos, entre eles Tomás de Mercado, Martín de Ledesma e Domingos de Souto continuavam a questionar a legitimidade da escravidão dos africanos e a ideia de que todos eram cativos de guerras

37 Saunders, A História Social, pp. 43-4; Linda M. Heywood e John K. Thornton, Central Africans, Atlantic Creoles, and the Making of the Foundation of the Americas, 1585-1660, Nova York: Cambridge University Press, 2007, pp. 70-2; José C. Curto, "Experiences of Enslavement in West Central Africa", Histoire Sociale/Social History, v. 41, n. 82 (2008), pp. 381-415.

38 Elizabeth Donnan (org.), Documents Illustratives of the History of the Slave Trade, Washington, D.C.: Carnegie Institute, 1930, v. 1, pp. 123-4. Para mais sobre o assunto ver Alencastro, $O$ trato dos viventes. 
justas ou santas. Apesar das críticas, a Coroa portuguesa, em parte pelo apoio que recebia dos jesuítas, continuou a autorizar a comercialização dos africanos escravizados e seu envio às Américas com a justificativa da expansão do cristianismo. Em 1623, um decreto do rei Filipe III de Espanha tornou obrigatória a presença de um padre a bordo dos navios negreiros para atender às demandas espirituais dos escravos. ${ }^{39} \mathrm{~A}$ escravidão estaria assim restrita aos africanos não cristãos, mas esses, ainda que se convertessem posteriormente, não teriam direito à liberdade. Essa lógica é a mesma que se aplica à escravidão no mundo muçulmano. Não muçulmanos poderiam ser apreendidos em jihads, "guerras santas", e postos em cativeiro. Assim como no mundo cristão, caberia ao proprietário, então, converter o cativo que permaneceria assim escravo, dispondo inclusive do controle sobre a sua descendência. ${ }^{40}$ A legislação portuguesa se aplicava assim àqueles que viviam ou que se sentiam pertencentes a uma, ainda que incipiente, noção de comunidade portuguesa. Entre esses estariam incluídos não só as autoridades coloniais e seus familiares, inclusive esposas e filhos nascidos localmente, como degredados do império, comerciantes e marinheiros, dependentes e vassalos, escravos e todos aqueles reconhecidos como cristãos.

Os oficiais coloniais portugueses reconheciam a limitação de suas ações em Benguela e as motivações dos seus pares. Em 1652, Bento Teixeira, ouvidor e provedor da fazenda de Angola, denunciou as guerras de expansão colonial que serviam de pretexto para escravizar populações vizinhas. Segundo ele, "tomam os governadores honestos pre-

39 Saunders, A História Social, p. 44.

40 A historiografia sobre escravidão islâmica é extensa. Entre outros, ver, Chouki El-Hamel, "The Register of the Slaves of Sultan Mawlay Isma'il of Morocco at the Turn of the 18th Century", Journal of African History, v. 51, n. 1 (2010), pp. 89-98; Ahmad Alawad Sikainga, "Slavery and Muslim Jurisprudence in Morocco", Slavery and Abolition, v. 19, n. 2 (1998), pp. 57-72; Paul E. Lovejoy, "Islam, Slavery, and Political Transformation in West Africa: Constrains on the Trans-Atlantic Slave Trade", Outre-Mers, Revue d'Histoire, v. 89, n. 2 (2002), pp. 247-82; Ghislaine Lydon, "Islamic Legal Culture and Slave-Ownership Contests in 19th century Sahara", International Journal of African Historical Studies, v. 40, n. 3 (2007), 391-435; e Bruce S. Hall, A History of Race in Muslim West Africa, 1600-1960, Nova York: Cambridge University Press, 2011, entre outros. Para a semelhança entre o sistema jurídico com respeito à escravidão ver, Mariza de Carvalho Soares. "A conversão dos escravos africanos e a questão do gentilismo nas Constituições Primeiras da Bahia", in Bruno Feitler e Evergton Sales Souza (orgs.), A Igreja no Brasil. Normas e práticas durante a vigência das Constituições Primeiras do Arcebispado da Bahia (São Paulo: Unifesp, 2011), pp. 303-21. 
textos para fazer guerra aos gentios sem na realidade haver outra causa mais que a cobiça de cativá-los e vendê-los, atropelando as leis da natureza". ${ }^{41}$ Assim, o estado colonial reconhecia que as guerras de expansão, classificadas como guerras justas, eram motivadas pela perspectiva de lucro e ganhos pessoais. Entretanto, essas autoridades coloniais eram incapazes de garantir militarmente o controle territorial, por isso, através da assinatura de tratados de vassalagem e alianças com as autoridades africanas, criavam um discurso de direito, dependência militar e reconhecimento de seu controle sobre os territórios e os súditos da Coroa portuguesa. Tratados de vassalagem reconheciam demandas políticas e geográficas de aliados políticos e comerciais e distinguiam os protegidos ou não pela lei colonial, criando dicotomias entre povos rebeldes e vassalos, cristãos e gentios, aliados e inimigos. ${ }^{42}$

Se por um lado o estado colonial dependia da cooptação e da colaboração dos sobas, por outro as autoridades locais viam seu poder legitimado e apoiado pela colônia que fornecia bebidas alcoólicas, tabaco, armas de fogo e fazendas aos sobas avassalados. ${ }^{43}$ A Coroa portuguesa não considerava essas transações como pagamento de tributo e sim como oferta de presentes. É importante destacar que o envio de pólvora, vinho, cachaça, chapéus, cintos, entre outros objetos, permitia a entrada de oficiais e comerciantes portugueses nos sobados não avassalados que ficavam fora do controle português, compondo os acordos para o uso do território por um período limitado de tempo. Ou seja, esses "presentes", como são chamados na documentação, selavam acordos diplomáticos entre os sobas e os representantes da Coroa portuguesa e inauguravam relações comerciais, abrindo caminho para a cobrança de impostos na forma de escravos, e criando como contrapartida a obrigatoriedade do envio regular de paga-

${ }^{41}$ AHU, Angola, cx. 5, doc. 101, 14 de dezembro de 1652.

42 AHU, Angola, cx. 9, doc. 25, 10 de abril de 1666. Sobre classificação e a linguagem de direitos, ver Pamela Scully, Liberating the Family? Gender and British Slave Emancipation in the Rural Western Cape, South Africa, 1823-1853 Portsmouth: Heineman, 1997, pp. 3446; e Karen B. Graubart, "Indecent Living: Indigenous Women and the Politics of Representation in Early Colonial Peru", Colonial Latin American Review, v. 9, n. 2 (2000), pp. 223-4.

43 Sobre a vassalagem ver Beatrix Heintze, "Luso-African Feudalism in Angola? The Vassal Treaties of the 16th to the 18th Century", Separata da Revista Portuguesa de História, v. 18 (1980), pp. 111-31; e Santos, "Escrever o poder", pp. 81-95. 
mentos, ou "presentes" ${ }^{44}$ Ao receber essas armas de fogo e bebidas alcoólicas, as autoridades locais tanto aumentavam seu poder bélico para captura de povos vizinhos e expansão territorial, quanto ampliavam a sua rede de dependentes, adquirindo mais escravos e população livre empobrecida em busca de proteção.

O tratado de vassalagem estabelecia, entre outras coisas, que a escravização de vassalos e aliados da Coroa portuguesa deveria ser evitada a todo custo. Em 1769, sob a responsabilidade do padre local, foi criado em Benguela o posto do inquiridor das liberdades, com a finalidade de regular a proteção dos vassalos e distingui-los dos escravos. A tarefa daquele religioso era "examinar os negros que vêm do negócio do sertão a serem vendidos e embarcados para o Brasil", para que "não suceda que entre os escravos se meta um livre". ${ }^{45}$ O pároco Manoel Gonçalves, o primeiro inquisidor das liberdades em Benguela, estava encarregado de

inquirir todos os escravos e marcá-los com a marca do rei na minha presença, não antes do batizado, mas sim depois de o serem, e que a igreja os mostre capaz de desembarcarem para esta lhe ficar servindo como último despacho, servindo igualmente de inquiridor de todas as causas das liberdade que se moverem nesse juízo, assinando as perguntas e respostas que se fizerem aos ditos pretos e procurando por eles todos os termos da sua liberdade. ${ }^{46}$

A criação desse cargo na segunda metade do século XVIII mostra não só como a incidência da escravidão era comum, mas também como ameaçava a todos, vassalos ou não, e juristas, assim como autoridades coloniais, discutiam as noções de escravidão, direito e proteção.

${ }^{44}$ Para casos semelhantes ao norte do rio Cuanza, ver Joseph C. Miller, Kings and Kinsmen: Early Mbundu States in Angola, Oxford: Clarendon Press, 1976, pp.177-79. Sobre o direito das autoridades de oferecer acesso à terra e o processo de interação com estrangeiros e comerciantes, ver Mahmood Mamdani, Citizen and Subject, Princeton: Princeton University Press, 1996, pp. 44-7; e Jeff Guy, "Analyzing Pre-Capitalist Societies in Southern Africa”, Journal of Southern African Studies, v. 14, n. 1 (1987), pp. 18-37.

45 ANTT, Conde de Linhares, maço 52, doc. 14, 24 de outubro 1769, "Provisão a Manoel Gonçalves para servir como inquiridor e catequizador em Benguela". Em Luanda esse posto foi criado anteriormente. Ver Ferreira, Cross-Cultural Exchanges, p. 54.

46 ANTT, Conde de Linhares, maço 52, doc. 14, 24 de outubro 1769, fl. 1. 
A nomeação do catequizador e inquiridor das liberdades dava continuidade ao bando de 1765, no qual o governador Francisco Inocêncio de Sousa Coutinho promulgou uma série de decretos proibindo o envolvimento, direto ou não, de autoridades coloniais no tráfico de escravos. Esses bandos e decretos eram tentativas de controlar a escravidão e proteger os direitos dos vassalos da Coroa portuguesa. Sem embargo foram todos letra morta, nunca respeitados em Benguela. As autoridades coloniais em Benguela estavam mais interessadas em garantir o seu próprio enriquecimento do que em obedecer às limitações impostas pelo governador geral, em Luanda. Capitães, governadores e soldados continuavam a atacar tanto povos gentios quanto vassalos. A captura e venda de vassalos, como será analisado a seguir, indica essa arbitrariedade. Assim, podemos afirmar que o lucro do tráfico se alastrou não só entre autoridades africanas locais mas também entre os portugueses que ali estavam, supostamente, para organizar e legalizar o comércio de seres humanos. ${ }^{47}$

Autoridades coloniais e juristas continuavam a debater quem podia ou não ser capturado e legalmente vendido para às Américas. Em 1770, Sousa Coutinho publicou um bando proibindo a escravidão por dívidas, com a intenção de proteger aqueles que viviam sob a autoridade da Coroa portuguesa mas que poderiam ter contraído dívidas. ${ }^{48}$ Vários ca-

47 Arquivo Histórico Nacional de Angola (AHNA), Cod. 443, fl. 117, 17 de fevereiro de 1803. Ver também Carlos Couto, "Regimento de Governo Subalterno de Benguela", Studia, v. 45 (1981), pp. 288-89; Carlos Couto, Os Capitães-Mores em Angola, Lisboa: Instituto de Investigação Científica e Tropical, 1972, pp. 323-33; Rosa da Cruz Silva, "Saga of Kakonda and Kilengues: Relations between Benguela and Its Interior, 1791-1796”, in José C. Curto e Paul E. Lovejoy (orgs.), Enslaving Connections: Changing Cultures of Africa and Brazil During the Era of Slavery (Amherst, N.Y.: Humanity Books, 2003), pp. 245-46; e José C. Curto, Enslaving Spirits: The Portuguese-Brazilian Alcohol Trade at Luanda and Its Hinterland, c. 1550-1830, Leiden: Brill, 2004, p. 94.

48 AHNA, Cod. 80, fl. 1-1v, 12 de novembro de 1771; Candido, Fronteras de esclavización, pp.163-64. Escravidão por dívida era comum em outras partes do continente africano. Ver, por exemplo, Jan Vansina, "Ambaca Society and the Slave Trade C. 1760-1845", The Journal of African History, v. 46, n. 1 (2005), pp. 1-27; Olatunji Ojo, “Ėmú' (Àmúyá): The Yoruba Institution of Panyarring or Seizure for Debt", African Economic History, v. 35 (2007), pp. 31-58; Jennifer Lofkrantz and Olatunji Ojo, "Slavery, Freedom, and Failed Ransom Negotiations in West Africa, 1730-1900", The Journal of African History, v. 53, n. 1 (2012): 25-44; Paul E. Lovejoy e Toyin Falola (orgs.), Pawnship in Africa: Debt Bondage in Historical Perspective (Boulder: Westview Press, 1994); e Paul E. Lovejoy e David Richardson, "Trust, Pawnship, and Atlantic History: The Institutional Foundations of the Old Calabar Slave Trade", The American Historical Review, v. 104, n. 2 (1999), pp. 333-55. 
sos, no entanto, indicam que a lei continuava sendo violada no sertão de Benguela. ${ }^{49}$ Esses processos revelam como as pessoas eram capturadas, oferecendo um lado humano para um comércio geralmente tratado com frieza nas fontes coloniais. É através dessa documentação oficial que os procedimentos da captura e da escravização são revelados.

A ênfase na literatura sobre o tráfico associado às guerras, enquanto mecanismo de aquisição de escravos, obscurece o fato de que nem todos os africanos que chegaram às Américas como escravos foram capturados em conflitos bélicos. ${ }^{50}$ Não resta dúvida que as guerras, razias e conflitos políticos resultaram em grande número de cativos, avidamente consumidos pelos comerciantes transatlânticos. Num ciclo vicioso, a comercialização ao longo da costa levava à ocorrência de mais guerras e conflitos armados. Especialistas em história da África, há décadas, enfatizam como alguns líderes e comerciantes africanos participaram no tráfico de escravos. Quanto a África centro ocidental, Jan Vansina, Beatrix Heintze, Joseph Miller, John Thornton, José Curto, Linda Heywood, Catarina Madeira Santos e Roquinaldo Ferreira demonstraram como sobas, sobetas e outras autoridades políticas estavam involucrados no comércio atlântico e dependentes dos seus lucros e mercadorias. ${ }^{51}$ Em alguns casos, pessoas foram escravizadas em outras situações, como o caso dos condenados por crime, dívida, ou aqueles simplesmente sequestrados ou enganados por conhecidos ou autoridades coloniais, que se aproveitaram da instabilidade política para cap-

49 Ver os vários casos listados por Candido, Fronteras de esclavización, pp.155-203.

50 Thornton, Warfare in Atlantic Africa; Walter Rodney, "Jihad and Social Revolution in Futa Djalon in the Eighteenth Century", Historical Society of Nigeria, v. 4 (1968), pp. 269-84; Lovejoy, Transformations in Slavery, pp. 68-90; Patrick Manning, Slavery and African Life: Occidental, Oriental, and African Slave Trades, Cambridge: Cambridge University Press, 1990; Robin Law, The Oyo Empire, C.1600-C.1836: A West African Imperialism in the Era of the Atlantic Slave Trade, Oxford: Clarendon Press, 1977; Barry, Senegambia and the Atlantic Slave Trade; e Martin A. Klein, "Social and Economic Factors in the Muslim Revolution in Senegambia", The Journal of African History, v. 13, n. 3 (1972), pp. 419-41.

51 Vansina, "Ambaca Society", pp.1-27; Heintze, "Ngingi a Mwiza; "Miller, Way of Death; John K. Thornton, "African Political Ethics and the Slave Trade", in Derek R. Peterson (org.), Abolitionism and Imperialism in Britain, Africa, and the Atlantic (Athens: Ohio University Press, 2010), pp. 38-62; Curto, Enslaving Spirits; Linda Heywood, "Slavery and its Transformation in the Kingdom of Kongo: 1491-1800", Journal of African History, v. 50 , n. 1 (2009), pp. 1-22; Santos, "Administrative Knowledge in a Colonial Context"; e Ferreira, "Slaving and Resistance", pp. 111-30. 
turar pessoas livres em situações vulneráveis. ${ }^{52}$ Apesar dessa instabilidade que caracterizou o período do comércio atlântico, leis locais e coloniais surgiram para regulamentar quem era passível de captura. A escravidão, assim, podia ser questionada e até revertida de modo a garantir que a liberdade original do indivíduo fosse preservada. ${ }^{53}$

\section{Os vulneráveis: mulheres e estrangeiros}

No dia 21 de junho de 1765, dom Francisco Inocêncio de Sousa Coutinho, governador de Angola, publicou uma portaria ordenando a José dos Santos Ferreira, então capitão-mor do presídio de Caconda, que libertasse imediatamente a jovem de nome Juliana. Segundo Sousa Coutinho, Juliana não podia lhe servir como escrava porque tinha em seu poder uma carta de alforria. Servir como escrava e ter carta de alforria eram para ele "qualidades entre si contrárias e repugnantes" pois ninguém pode "ser livre e viver como escrava". ${ }^{4}$ Segundo o relato, o capitão José dos Santos Ferreira comprara Juliana em praça pública no presídio de Caconda, no início de 1765. Passados alguns dias, em nome da família de Juliana, chegou a Benguela um embaixador do potentado de Kissange, em Quilengues, chamado Xaucuri. Ele vinha encarregado de negociar com o capitão o resgate de Juliana, oferecendo em troca de sua liberdade um escravo ("peça da Índia") e dez cabeças de gado. O capitão aceitou a proposta de resgate mas pediu dois escravos, além das dez cabeças de gado. Xaucuri retornou a Kissange para conseguir os recursos para o segundo escravo e passou meses sem dar notícias. Nesse meio tempo o capitão José dos Santos Ferreira concedeu a Juliana uma alforria condicional, vinculando sua liberdade ao pagamento da peça da Índia restante. O silêncio de Xaucuri estava provavelmente re-

52 José C. Curto, "Struggling Against Enslavement: The Case of José Manuel in Benguela, 181620", Canadian Journal of African Studies, v. 39, n. 1 (2005), pp. 96-122; Curto, "The Story of Nbena", pp. 44-64; Roquinaldo Ferreira, "O Brasil e a arte da guerra em Angola (sécs. XVII e XVIII)", Estudos Históricos, v. 1, n. 39 (2007), pp. 3-23; Candido, Fronteras de esclavización, pp. 178-90.

${ }^{53}$ Ferreira, "Slaving and Resistance”, pp. 96-122; e Candido, “African Freedom Suits”, pp. 447-59.

54 ANTT, Conde de Linhares, Livro 50, v. 1, fl. 142 v-144, São Paulo de Assunção de Luanda, 21 de junho de 1765 . 
lacionado à destruição do potentado de Kissange pelo exército do soba Kibanda em meados da década de 1760.

Assim como Juliana, outras pessoas já portadoras de nomes portugueses, expostas à cultura e, de certa forma, ao colonialismo português, foram violentamente capturadas e escravizadas em regiões próximas ao litoral da África centro ocidental. Não sabemos se Xaucuri chegou a Kissange antes, durante ou logo depois do ataque, nem como ele e a família de Juliana foram afetados pelo conflito. Mas sem a ajuda da família, a jovem corria o risco de continuar escravizada pelo resto de sua vida, ou ainda ser vendida a comerciantes transatlânticos e enviada às Américas. Sua salvação parece ter sido o entendimento do governador de Angola que, por portaria, lhe deu a liberdade. As fontes não revelam o final da história: se ela foi efetivamente libertada, se retornou a Kissange; e se lá chegou, em que condições teria voltado ao convívio de seus familiares. Esse caso demonstra como escravidão e liberdade eram assuntos que preocupavam as autoridades coloniais estabelecidas em Benguela, assim como a população local; também demonstra a existência de um debate a respeito da escravidão em Angola em meados do século XVIII; e por fim, aponta para a disputa de autoridade entre os representantes coloniais portugueses em Luanda (o governador) e no interior de Benguela (o capitão). Quando o governador Francisco de Sousa Coutinho questionou a escravidão de Juliana, o debate jurídico a respeito da legalidade da escravidão não era uma novidade. Como foi destacado anteriormente, a polêmica era tão antiga quanto a expansão portuguesa e era marcada não só pelas experiências anteriores na Senegâmbia e no Congo, como também pelo debate sobre a escravidão indígena nas Américas.

O caso de Juliana, capturada nos arredores do presídio de Quilengues e vendida como escrava no presídio de Caconda, não é único. Só sabemos seu nome católico, indicando que ela provavelmente foi batizada ou vivia em contato com a cultura portuguesa. Não sabemos os nomes de seus pais ou a sua idade, e a documentação existente revela que o tempo entre sua captura, venda e transporte até Benguela foi relativamente curto. Em casos semelhantes, quando as autoridades coloniais tinham que arbitrar sobre liberdades, os escrivães detinham-se em explicar o processo de captura. No caso de Juliana não há qualquer 
menção às razões que a levaram a sua escravização. Apesar de desconhecer as circunstâncias da captura, Sousa Coutinho indignou-se com o fato de ela continuar a viver como escrava após o seu proprietário - um membro da força colonial portuguesa - concordar com o seu resgate e lhe oferecer uma carta de alforria condicional.

Outro caso chamou a atenção das autoridades e foi arbitrado pelo governador de Benguela. Em 1789, o inquiridor das liberdades descreveu a captura ilegal de carregadores livres do sobado do Bailundu quando estavam no porto de Benguela. Ao contrário do caso de Juliana, sabemos em que circunstâncias esses carregadores foram enganados e capturados por um sertanejo. Depois da caravana em que trabalhavam chegar ao porto, o sertanejo Antônio José da Costa resolveu vender o marfim, a cera, os escravos que trazia do interior, e também os carregadores. Talvez o contrato de trabalho estabelecido tenha se consumado sob coerção do soba do Bailundu, mas usualmente os carregadores que eram trabalhadores livres recebiam pagamento e retornavam em segurança ao planalto de Benguela. O caso foi levado ao governador que garantiu aos carregadores seu regresso a Bailundu. ${ }^{55} \mathrm{O}$ episódio mostra a vulnerabilidade das pessoas que se encontravam distantes de suas terras, estrangeiros, privados da proteção de seus governantes e familiares, e por isso vulneráveis a sequestros, com o risco de serem vendidos a terceiros, sem o conhecimento de seus protetores.

Em 1811, outro caso chamou a atenção das autoridades coloniais em Luanda. Mais uma vez oficiais de Benguela, ao invés de protegerem os súditos portugueses, aproveitaram-se da sua vulnerabilidade. No começo da década de 1810, dona Leonor de Carvalho Fonseca, uma comerciante mulata residente em Benguela, foi ao sobado do Bailundu com o objetivo de cobrar as dívidas que o soba e outros comerciantes do sobado haviam contraído com seu falecido marido. Mulher livre, dona Leonor viajou na companhia de duas filhas ainda pequenas. A viagem deveria ter transcorrido sem maiores consequências, mas ao chegar a Bailundu dona Leonor foi surpreendida e escravizada. No mesmo ano que declarou vassalagem à Coroa portuguesa, concordando em

55 AHU, Angola, cx. 74, doc. 15 e 21 de abril de 1789. 
proteger os pombeiros e comerciantes itinerantes que viajassem por suas terras, o soba do Bailundu ordenou a captura de dona Leonor e suas filhas. A violação do tratado por parte do soba pode ser entendida como um ato político contra uma comerciante luso-africana, e ao mesmo tempo representava uma afronta ao estado colonial. ${ }^{56} \mathrm{~A}$ decisão de escravizar uma comerciante deve ser vista como uma disputa política com as forças coloniais sobre as obrigações da vassalagem, entre elas a proteção de comerciantes e o pagamento de tributos em escravos. Depois de sua captura e escravização, dona Leonor e as duas filhas foram vendidas a um sertanejo que as transportou de volta à cidade de Benguela. Dona Leonor foi vendida ao capitão do navio Grão Penedo e levada a bordo para ser enviada ao Rio de Janeiro, depois de uma parada em Luanda. Provavelmente dona Leonor comercializava diversas mercadorias e também escravos. Ironicamente, foi escravizada, e forçada a regressar a Benguela presa a um libambo numa caravana que trazia escravos do interior, exatamente como ela e seu marido devem ter feito outras vezes. ${ }^{57}$

Por motivos não esclarecidos, talvez porque estivesse mais interessado em seu lucro pessoal, o governador de Benguela preferiu ignorar o fato de que dona Leonor falava português, residia em Benguela e era comerciante de escravos. Ao invés de proteger a viúva do comerciante, apreendeu suas duas filhas e as manteve em cativeiro, empregando-as como escravas domésticas em sua residência oficial. Em uma pequena cidade de menos de três mil moradores é difícil imaginar que o governador não conhecesse dona Leonor. Quando o Grão Penedo chegou a Luanda, a história de dona Leonor foi relatada ao então governador de Angola, José de Oliveira Barbosa. A informação pode ter vindo do padre que cumpria as funções de inquiridor das liberdades e visitou o navio. Em sua defesa dona Leonor alegou ser vassala e mulata (indicando ser descen-

${ }^{56}$ AHNA, Cod. 323, fl. 28v-29, 19 de agosto de 1811; AHNA, Cod. 323, fl. 30v-31, 20 de agosto de 1811. Para maiores detalhes, ver Candido, "African Freedom Suits".

57 Sobre o funcionamento das caravanas no interior de Benguela ver Maria Emília Madeira Santos, Nos caminhos de África: Serventia e posse, Angola século XIX, Lisboa: Instituto de Investigação Científica Tropical, 1998; Linda M. Heywood, "Production, Trade and Power: The Political Economy of Central Angola, 1850-1930" (Tese de Doutorado, Columbia University, 1984), pp. 190-208; Mariana Candido, "Merchants and the Business of the slave trade at Benguela, 1750-1850", African Economic History, v. 35 (2007), pp. 1-30. 
dente de portugueses e protegida pela legislação portuguesa) e ter sido ilegalmente capturada e vendida no Bailundu. A saga de dona Leonor chamou a atenção das autoridades de Angola, que intervieram, libertando a comerciante e ordenando o seu regresso imediato à Benguela e reencontro com suas filhas. Ainda que o caso tenha sido resolvido em benefício de dona Leonor, o mesmo revela a expansão da instabilidade, a força penetrante e ameaçadora da escravidão e o envolvimento ativo de autoridades coloniais nos processos de escravização. O governador de Benguela estava mais interessado em ganhos pessoais do que na proteção de súditos e a garantia do respeito às leis da Coroa portuguesa.

Negros livres, especialmente os sertanejos e pombeiros, eram particularmente vulneráveis ao cruzar fronteiras políticas, atuar em distintos mercados e estados. O lucro do comércio de escravos provavelmente era atrativo o suficiente para justificar os riscos que corriam. Suas atividades econômicas não os protegiam da escravidão e o transporte de bens considerados valiosos, como os tecidos, armas, pólvoras e bebidas alcoólicas, os tornavam presas cobiçadas. Os chamados lusoafricanos que viviam dentro ou fora de regiões sob controle português tinham uma situação bastante precária, ao transitar por estados em conflito com as forças coloniais ou mercados controlados por sobas que resistiam ao poderio militar e comercial português. Como os casos aqui analisados indicam, os comerciantes itinerantes eram frequentemente atacados, indicando que os sobas viam com desconfiança a presença dos agentes comercias associados à economia atlântica.

Aos casos dos carregadores de Bailundu e de dona Leonor se juntam ao episódio de Quitéria, "filha de Antônio Pilarte já falecido e de Maria Francisca assistente no sertão de Caconda". ${ }^{58}$ Quitéria era originalmente de Caconda, mas se encontrava em Benguela na década de 1830 como aprendiz de costureira. Sabemos sobre a captura de Quitéria porque dona Maria José de Barros, residente livre naquele porto, pediu o auxílio do governador para punir o culpado pelo sequestro da jovem. Quitéria, uma "rapariga livre", morava na casa de dona Maria José de Barros, de quem era "discípula" porque lhe havia sido entregue "para

${ }^{58}$ AHNA, Cod. 450, fl. 49v-50, 20 de fevereiro de 1837. 
educar com o ofício de costureira e outros que lhe são relativos". Dona Maria José, natural de Benguela, era casada com o capitão do exército de Benguela, José Joaquim Domingues, natural de Braga. ${ }^{59}$ Num determinado dia, sem motivo aparente, o capitão Domingues levou a jovem Quitéria até o porto e a vendeu a quem lhe ofereceu mais por uma suposta escrava que falava português. Quando dona Maria José percebeu o que havia acontecido, teve uma discussão com o capitão, tendo sido "espancada e mal tratada por motivos casarios, entre os quais o de haver esse antes encaminhado, vendido e já embarcado a bordo uma rapariga livre de nome Quitéria, sua discípula". ${ }^{60}$ Depois da agressão, dona Maria José foi rapidamente ao porto para localizar Quitéria e lá a encontrou dentro de um navio, já marcada a ferro. Dona Maria José salvou Quitéria do cativeiro oferecendo outro escravo em seu lugar. O governador de Benguela, Justiniano José dos Reis, interveio no caso pedindo ao juiz de paz e órfãos que investigasse o capitão "pelo procedimento de usurpador da liberdade e marcador de pessoas livres com marca de ferro quente". ${ }^{61} \mathrm{O}$ juiz ordenou a prisão domiciliar do capitão por seis meses, por considerar que o crime não foi sério, afinal "a dita preta a bordo, foi finalmente por requisições e queixumes da consorte do réu, outra vez desembarcada para terra, ficando deste modo sem efeito a venda que dessa tinha feito". ${ }^{6}$ Assim, como nos casos anteriores, a ação de familiares e conhecidos salvou Quitéria do embarque e do envio ao Brasil, mas não impediu o embarque do outro cativo posto eu seu lugar que não teve ninguém que intercedesse por ele. Ou seja, ao validar a venda de uns para a proteção de outros, o pagamento de resgate reforçava a instituição da escravidão. Neste episódio a atitude do capitão demonstra mais uma vez que, apesar das constantes proibições, diversas autoridades coloniais participaram ativamente do comércio de escravos. ${ }^{63}$

59 O assento do casamento entre dona Mariana José de Barros e o capitão Domingues foi registrado no Arquivo do Arcebispado de Luanda (AAL), Benguela, Casamentos, 1806-1853, fl. 36, 7 de junho de 1830 .

${ }^{60}$ AHNA, Cod. 450, fl. 49v-50, 20 de fevereiro de 1837.

${ }^{61}$ AHNA, Cod. 450, fl. 49v-50, 20 de fevereiro de 1837.

${ }^{62}$ AHNA, Cod. 509, fl. 211V, 17 de março de 1837.

${ }^{63}$ Para mais sobre o assunto, ver Candido, Fronteras de esclavización, pp. 190-202; Selma Pantoja, "Gênero e comércio: as traficantes de escravos na região de Angola", Travessias, n. 4/5 (2004), pp. 79-97; José C. Curto, "Struggling Against Enslavement, pp. 96-122; Ferreira, "O Brasil e a arte da guerra em Angola, pp. 3-23. 
Tanto em Benguela como no interior, o uso de violência era comum e até essencial para manutenção do tráfico de escravos. Lamentavelmente, a não ser em casos pontuais, a informação hoje disponível é limitada às fontes coloniais portuguesas e oferecem poucos detalhes sobre os mecanismos de escravização em regiões fora do controle português. Pode-se apenas imaginar que as pressões do mundo atlântico desempenhassem um papel vital na forma como os sobas e seus auxiliares puniam crimes e vendiam como escravos aqueles considerados perigosos por questões políticas ou sociais. A gama de crimes punidos com a escravidão deve ter aumentado nos sobados do sertão de Benguela para atender à demanda constante por escravos, assim como aconteceu em outras regiões do continente africano. ${ }^{64}$ Pessoas livres, ainda que vassalas e cristãs, eram escravizadas na esteira da expansão do comércio transatlântico, como os casos de Juliana, dona Leonor e suas filhas e Quitéria demonstram. Pelos exemplos disponíveis, fica claro que o sequestro tornou-se uma estratégia frequente para escravizar pessoas em situação vulnerável: era o caso dos comerciantes volantes e das mulheres que se encontravam distantes da proteção de familiares e figuras politicamente mais poderosas. Ainda que os parentes tentassem acudir e resgatar familiares, como no caso de Juliana e Quitéria, as liberdades não estavam garantidas e ficavam sujeitas aos desejos e vontades dos proprietários (ou supostos proprietários). A intervenção da autoridade colonial ou dos familiares geralmente era tardia e não prevenia o cativeiro; quando muito o envio para as Américas, provavelmente para o Brasil. Em casos de pagamento de resgate, é evidente que a liberdade das ditas "peças da Índia" não era questionada, pois eram oferecidas como escravos legítimos em troca de liberdade de pessoas melhor posicionadas. A linha entre a liberdade e escravidão era tênue para todos, mas os mais distantes do mundo colonial português, ou seja, aqueles que desconheciam as leis, a língua portuguesa ou pessoas que os pudessem proteger, estavam em situação ainda mais vulnerável. ${ }^{65}$

${ }^{64}$ Candido, Fronteras de esclavización, pp. 175-77; e Lovejoy, Transformations in Slavery, pp. 66-85.

65 Ver Keila Grinberg, Liberata: a lei da ambiguidade: as ações de liberdade da Corte de apelação do Rio de Janeiro no seìculo XIX, Rio de Janeiro: Relume Dumará, 1994; Sidney Chalhoub, A força da escravidão, São Paulo: Companhia das Letras, 2012; Rebecca J Scott, "Paper Thin: 
O pagamento do resgate, assim como o uso das autoridades portuguesas para decidir o destino de africanos capturados, legitimava a instituição da escravidão. A escravidão foi normatizada através dos códigos, com a pressuposição de que algumas pessoas eram "legalmente" escravizadas. A violência inerente à expansão do comércio transatlântico de escravos transformou as noções de legalidade e teve um efeito devastador na região de Benguela, reforçando o papel dos colonizadores como árbitros de conflitos que ocorriam entre segmentos da população local.

\section{Conclusão}

A ausência de relatos autobiográficos de escravos oriundos da África centro ocidental não significa a impossibilidade de saber como as pessoas eram escravizadas nessa região. A documentação colonial portuguesa revela casos de centro-africanos que foram enganados e capturados, às vezes em localidades próximas a Benguela. Além dos cativos de guerra, há casos de pessoas sequestradas na cidade de Benguela, como os carregadores; em sobados no interior, como dona Leonor e os pombeiros; e nos presídios portugueses, como Juliana. Em todos eles, a participação de funcionários coloniais determinou a sua captura e perda da liberdade. Esses casos tratam a escravidão como uma experiência individual e não anônima, como tende a ser o caso dos estudos demográficos. Ainda que os cativos não tenham registrado suas memórias, a documentação colonial revela a vulnerabilidade da população local que, embora livre, era constantemente ameaçada pela violência do tráfico de escravos. O tráfico afetou não só aqueles que foram enviados às Américas, mas também aqueles que ficaram no continente africano sob ameaça do cativeiro. Guerras, razias e sequestros levaram à instabilidade política, ao colapso, à emergência de estados e à legitimação da instituição da escravidão.

Já temos estimativas do número de escravos embarcados nos por-

Freedom and Re-Enslavement in the Diaspora of the Haitian Revolution", Law and History

Review, v. 29, n. 4 (2011), pp. 1061-87; e Rebecca J. Scott e Jean M. Hébrard, Freedom Papers: An Atlantic Odyssey in the Age of Emancipation, Cambridge: Harvard University Press, 2012. 
tos de Loango, Luanda e Benguela, mas ainda não entendemos a complexidade dos processos pelos quais as pessoas foram escravizadas. Outros estudos precisam ser feitos para melhor entendermos a dimensão do impacto social do tráfico de escravos nas sociedades da África centro ocidental. Ao generalizar as experiências da captura como "cativos de guerra", invisibilizamos todas as demais formas de escravização, negandolhes um lugar na história. Para evitar generalizações sobre as populações que chegaram ao Brasil durante o tráfico transatlântico de escravos, é preciso saber quem eram essas pessoas capturadas, de onde vinham e que língua falavam. Nem todos os escravos exportados da África centro ocidental foram capturados e vendidos da mesma forma e certamente as condições de sua escravização influenciaram o modo como entendiam a instituição e as expectativas que vieram a ter nas Américas.

Ainda que a informação disponível seja limitada e pontual, ela permite várias conclusões: primeiro, a escravização contou com a participação direta de autoridades coloniais portuguesas; segundo, ainda que seja difícil estimar o seu número, algumas das pessoas escravizadas e provavelmente exportadas a partir de Benguela estavam familiarizadas com o colonialismo, a legislação e a língua portuguesa; terceiro, com a expansão do comércio atlântico, o sequestro tornou-se constante no sertão de Benguela; quarto, sem poupar nem mesmo os vassalos do rei de Portugal, a escravidão tornou-se difusa e universal na região; e quinto, através da expansão da violência e da insegurança, as autoridades portugueses transformaram-se em árbitros de episódios de captura ilegal, favorecendo a legitimação da escravidão aos olhos de todos os envolvidos. Noções como "liberdade original," "legalmente ou ilegalmente capturados", tornaram-se expressões correntes na documentação colonial. O impacto do tráfico transatlântico foi profundo, ameaçando tanto a população que vivia próxima à costa quanto no interior, participantes ou não do comércio atlântico. Ainda que o efeitos sociais sejam mais difíceis de medir do que os demográficos, os casos narrados revelam a expansão da violência, a instabilidade política e a força destruidora das razias e guerras no contexto no comércio atlântico de escravos.

Texto recebido em 17 de outubro de 2012 e aprovado em 3 de dezembro de 2012 


\title{
Resumo
}

O artigo examina processos de captura e escravização na região de Benguela, África centro ocidental. Apesar de a historiografia sobre escravidão e o tráfico de escravos enfatizar a guerra como principal mecanismo de captura, vários casos indicam que um número significativo de indivíduos foram sequestrados por pessoas conhecidas. Além disso, foram capturados em localidades sob o domínio português, próximos à costa, relativizando a ideia de que na primeira metade do século XIX a maioria dos escravos era oriunda do interior do continente. Vários temas consagrados na historiografia, como o movimento progressivo e cronológico da fronteira escravista e o papel dos líderes africanos no processo de escravização são problematizados nesse estudo. Os casos analisados permitem perceber a participação sistemática de agentes coloniais portugueses no processo de escravização. Ao priorizar casos individuais, o texto aponta para uma dimensão única da captura no continente africano que tende a ser obscurecida por análises demográficas.

Palavras chaves: escravidão - captura - Benguela - inquisidores das liberdades

\begin{abstract}
Focusing on the line separating freedom and slavery in Benguela in West Central Africa, this study addresses a series of debates in the historiography of slavery and slave trade in Africa. Challenging a historiography that tends to portray every African slave as a captive of war, this study explores the cases of individuals kidnapped and betrayed. In some cases, they were able to retell their stories of capture, allowing an understanding of the enslavement process as an individual experience, rather than a collective and unanimous one, emphasized by demographic studies. Some of these slaves were captured in regions along the coast during the early nineteenth century, contesting the idea of the progressive and chronological movement of the enslaving frontier. Some Africans were captured and enslaved along the coast, not in the interior. Portuguese colonial agents were directly involved in the systematic capture of free Africans.
\end{abstract}

Keywords: Slavery - capture- Benguela - freedom inquisitors. 